\title{
THE LIMITS OF STABILIZATION POLICIES
}

\author{
TANZI, Vito
}

That fiscal policy may have limits has been known and has been discussed since 1936, when Keynes published The General Theory in the middle of the Great depression. The criticism of countercyclical fiscal policy should have changed over the years, because of economic, social and structural changes that have taken place in the economies of the countries. This paper focuses on changes in the socio-economic ecology of countries and argues that those changes are likely to have reduced the effectiveness of traditional countercyclical fiscal policy.

Keywords: fiscal policy, Keynesianism, stabilization policy

JEL classification indices: B22, E32, E62, H30

Tanzi, Vito, has been a Professor of Economics, is Honorary President of the International Institute of Public Finance, and former Director of the Fiscal Affairs Department at the IMF.

E-mail: vitotanzi@msn.com 


\section{INTRODUCTION}

This paper was written for the present Special Issue of Acta Oeconomica, to commemorate the $70^{\text {th }}$ birthday of Grzegorz Kołodko. When Greg was Minister of Finance of Poland, and I was at the IMF, we had some occasions to discuss the policies that Poland should adopt to stimulate its economy. In 2001-2003, when I was part of the Italian government, we met in Rome and we discussed similar issues. I do not recall what advice, if any, I gave him. I was also happy to have contributed to some books that he edited. See references. This paper might be useful to Greg, should he find himself again in a position to influence the economic policy of Poland. I am glad that his birthday gave me the opportunity and the incentive to think deeply about stabilization policies and their limitations and to write a related paper. I am grateful to Acta Oeconomica for inviting me to write about them.

\section{FISCAL POLICY AND CHANGES IN SOCIO-ECONOMIC CONDITIONS}

This paper discusses some issues in fiscal policy that are likely to have become more important in recent years but that have not received the attention that they may merit'

We shall start by mentioning that changes, in recent decades, in what could be called the socio-economic ecology in which modern economies operate, may have reduced, or qualified, the importance of some of the theoretical criticisms mentioned in Tanzi (2018c). For example, the fact that governments and large enterprises can now borrow more easily from global sources must have reduced the importance assigned in the past to domestic loanable funds. And the role of the global financial market, including commercial banks, hedge funds, investment banks, pension funds and other financial operators that operate in several countries, and the recent role played by central banks in lending to both governments and enterprises, through "quantitative easing" or through very low interest rates, must have also reduced the importance of the Ricardian Equivalence Hypothesis, by changing the more direct link that had existed in the past between national public debts and national taxpayers.

The socio-economic conditions (the ecology) within which the Keynesian fiscal policy now operates, are significantly different from those that existed in

1 For earlier discussions of some of them, see, Tanzi (2011, 2013, and 2015a). In many ways this paper should be read after my historical study on the development of Keynesian policies (and their criticisms) already published in the Special Issue of Acta Oeconomica, devoted to the $10^{\text {th }}$ anniversary of the 2008 global financial crisis (Tanzi 2018c). 
Keynes times. Today's world has: (a) larger governments' roles in the economy; (b) much higher public spending; (c) a global financial market, that can more easily finance national debts; (d) much more statistical information about economic developments in the world, with institutions specializing in forecasting and in providing better data; (e) more links among countries' economies, due to globalization; (f) more policy coordination among countries' governments; (g) much larger public and private debts; (h) more regulations on hiring and firing of workers: and so on.

In many countries there are also more structural constraints, including government or even non government regulations, on the actions of enterprises and individuals, than existed in the still largely laissez-faire environment that prevailed in the 1930s. These regulations, for example, minimum wages are likely to become more damaging to employment during downturns, when profits fall, for regulations related to the hiring of unskilled workers (Meyer 2018). It would, indeed, be strange if the major changes in the socio-economic ecology of the world, that took place over the past eight decades, had not had a significant impact on the effectiveness of Keynesian fiscal policies.

To provide a sample of one of these changes in the ecology, the US Bureau of Labour Statistics now lists 449 specific occupations, and many of these occupations (say those of doctor, dentists, etc.) include many specialized components that did not exist earlier. A century ago there were far less occupations and much more concentration in a few activities. For example, in 1910 "farm workers" accounted for 30.9 per-cent of all US workers; by 2015 they accounted for only 0.7 . On the other hand, "professional and technical" workers that in 1910 accounted for only 4.7 of the labour force, by 2015 had increased their share to 27.7 per cent. "Mining, manufacturing, construction and transportation and public utilities" combined, that in 1910 accounted for 58.2 of all employment (and with farm workers for 89.1 of all workers), in 2015 they accounted for only 17.5 per cent (and, combined with farm workers, for only 18.2 per-cent). These changes must have major implications for how a government's fiscal stimulus works its way through the various parts of the economy, when it is enacted. That stimulus, by necessity, is generally directed to particular areas, or particular sectors, of the economy and it requires that the unemployed workers move to different occupations and often to different places.

The other related paper (Tanzi 2018c) outlines the changing popularity of the Keynesian theories, over the 8 decades of their existence, from the initial scepticism, expressed by leading economists of the $1930 \mathrm{~s}$, to the almost religious trust in those ideas, during the years of the Keynesian Revolution ${ }^{2}$, to the scepticism

2 See, for example, the US 1962 Economic Report of the President. 
introduced by the rational expectation counterrevolution of later years. The latter revolution had a great influence on economic thinking in the 1980s and 1990s, and on many economists, though it had less on policy action, in the three decades that preceded the "Great Recession", as indicated by the growth in public debts in those years. Many prominent economists in those years had concluded that Keynesian fiscal policy was, or should be, dead; and many of them got Nobel Prizes in Economics.

The "Great Recession" of 2009-2010 brought a sudden and, to some extent, a surprising, revival of faith in countercyclical fiscal policies, both among economists and governments. Urged by a few, highly vocal economists, who for a while seemed to have monopolized the media, and also encouraged by some international organizations, including, at that time, the IMF (e.g. Spilimbergo et al. 2008), several governments introduced fiscal stimulus programs that were unprecedented in size and were mainly associated with higher public spending. By 2009-2010 the stimulus programs had helped create fiscal deficits that were much larger than ever before, in non-war years. In several countries, the deficits reached, or exceeded, ten per-cent of GDP (Table 1).

Table 1. Deficits in some countries, \% of GDP

\begin{tabular}{l|r|r|r|r}
\hline Country & 2007 & 2008 & 2009 & 2010 \\
\hline Greece & 6.1 & 6.7 & 15.1 & 11.2 \\
\hline Iceland & -6.3 & -5.4 & 9.6 & 9.7 \\
\hline Ireland & -2.9 & -0.1 & 13.8 & 32.8 \\
\hline Italy & 1.5 & 2.7 & 5.3 & 4.5 \\
\hline Japan & 2.4 & 4.2 & 9.5 & 10.2 \\
\hline Portugal & 3.1 & 3.5 & 9.8 & 11.2 \\
\hline Spain & -1.9 & 4.1 & 11.0 & 9.4 \\
\hline UK & 2.7 & 4.9 & 10.1 & 9.4 \\
\hline USA & 2.7 & 6.5 & 13.1 & 10.9 \\
\hline G7 countries & 2.1 & 4.8 & 9.9 & 8.8 \\
\hline G20 (advanced) & 0.9 & 2.8 & 9.5 & 8.4 \\
\hline
\end{tabular}

Source: IMF, Fiscal Monitor (April 2012, 2018).

The justification that was given for these extraordinary fiscal policies (and for similarly extraordinary monetary policies) was that the countries needed to be protected from the potential danger of falling into another, long and deep, "Great Depression", similar to that of the 1930s. While we shall never know what would have happened if governments had not intervened with these extraordinary measures, a few pertinent observations can be made.

First, there is no evidence to indicate that the countries that did not enact large fiscal programs in 2009-2010 did less well than those that did. Several countries, 
or economies (China, Hong Kong, Korea, Luxemburg, Singapore, Sweden, Denmark, Norway, Estonia, Switzerland, Taiwan and others), maintained approximate fiscal balance during the Great Recession, and they did not fall into depressions.

Second, as mentioned in the other paper (Tanzi 2018c), before the Keynesian Revolution, countries had frequently experienced downturns, at times very deep ones. They had always emerged from them, without the assistance of countercyclical fiscal policies.

Third, several of the countries that took major fiscal measures during the Great Recession accumulated large public debts (Tanzi 2016, 2018b). They will need to deal with the consequences of those debts in future years, when interest rates are likely to be significantly higher and when they will face higher public spending, especially on health and pensions, because of the future impact of demographic changes on public budgets. (Tanzi 2016). This fact will inevitably affect the future economic climate of the countries, their economic performances, and their fiscal sustainability. High public debt has been shown to lead to lower growth rates (Tanzi - Chalk 2000).

Fourth, as extraordinary as the fiscal deficits reported in Table 1 became, they would have been even larger if the central banks had not intervened, with interest rates kept at historically low levels; and so would have been the public debts (Tanzi 2015a). Monetary policy is not likely to remain, or that it can remain, as accommodating in future years. At the time when this paper was being completed, in June 2018, interest rates were already rising and were likely to continue rising. It is a reasonable assumption that several countries will face serious fiscal difficulties, and even fiscal crises, in future years. The USA is a good candidate to be one of them.

In Section 3 of this paper, we shall briefly explore some of the consequences of living with high debts, and some of the implications of promoting fiscal expansion, when the initial situations of the countries' public budgets are already precarious. We shall also take into account the impact of the changed socio-economic ecology on the results of expansionary fiscal policy. The issues discussed are obviously complex. They can be mentioned only briefly in this paper.

\section{CHANGING ECOLOGY AND IMPORTANCE OF INITIAL FISCAL CONDITIONS}

Counter-cyclical fiscal policy has generally been advocated by its promoters without paying adequate attention to the socio-economic ecology of the countries, and to the initial conditions of the fiscal accounts. The implicit assumption has been that the only variables that count are 
- the size of the fiscal stimulus and

- the factors that determine the size of the fiscal multiplier, such as imports and saving rates.

It should be observed that, strangely, there has been little or no discussion of the horizon over which the multiplier is supposed to exercise its impact during a fiscal expansion. Is the impact in the same year of the stimulus? Or is it distributed over several future years? Of course, the longer is the horizon, the lower is its immediate impact, and the more likely it is that the multiplier effect, if it exists, may become pro-cyclical. In the following, we briefly discuss some other factors, stressing that the same policies may have different results, when the ecology in which they operate is different (Tanzi 2018b).

The importance of the socio-economic ecology. During the recent "Great Recession", when the output of many countries fell and the unemployment rate rose sharply, there were frequent reports of enterprises that were desperately looking for workers to hire but were unable to find them (Tanzi 2013, Ch. 9: 89-94). Naturally they were not looking for any worker, but for workers with particular skills. If an economy were limited to one city (as, for example, are the economies of Singapore and Hong Kong), and if the workers who lived in that city were totally or mostly fungible - in the sense that each worker had approximately the same skills and ability to perform any tasks as any other -, then a fiscal stimulus that injected disposable income to the economy would be expected to have the largest, potential, expansionary, impact on output and on employment, given the "crowding outs" discussed in Tanzi (2018c), and given the size of the multiplier.

Given the above environment, the fiscal expansion would have an effect similar to that of discharging water on a flat surface. The water would spread and cover the whole surface. The fiscal expansion would not face mismatches, between the demand for workers, created by the stimulus program, and the supply of particular skills, given the needs of particular sectors. The demand for labour would easily meet the supply of labour; the right labour supply would be there to meet and satisfy the particular demand for workers. The (fungible) unemployed workers would be available to all employers; and they could be available in the same geographic area where they were needed. Resistance, in the transmission mechanism would be minimal.

However, in today's world, economies are fragmented by space and, far more importantly, by great differentiation of skills and specializations, as we saw earlier; and also by different needs for particular skills from different sectors. For example a fiscal expansion may create jobs in areas in which the skills are lacking or in far away areas. 
As countries become richer and more developed:

(a) the economies need more human capital;

(b) the human capital will acquire progressively more specialized skills;

(c) the number of different skills and specialized occupations will grow. As shown above for the USA, the number of different occupations, each requiring specialized training and skills that had not been needed in the past and had not existed is now far greater than in the past.

(d) In a smoothly-growing economy, one with a flexible labour market, without structural obstacles and with high, spatial mobility for the workers, the human capital will adjust over time, because it would face few frictions. It will acquire the skills that the market demands and requires.

(e) The workers will become progressively more specialized and, as a consequence, less fungible. They will learn more and more about how to deal with narrower tasks, and will become less able to deal with different tasks. Just think of today's specializations among doctors, dentists, or financial operators. That works well in a smoothly growing economy.

(f) However, when bubbles develop and generate higher incomes for the workers who have the skills required by the particular bubble sectors (finance, housing, energy), more workers will gravitate to those sectors, and more workers will acquire the required skills. The longer an economy experiences a particular bubble, the more workers will gravitate to that sector.

(g) The bubbles will also inflate the country's tax revenue and will distort (and inflate) the country's rate of growth, sending wrong signals to the market and to the policymakers. This happened in Ireland, Spain, Iceland, the United States and some other countries, in the years before the financial crisis (Tanzi 2018b, Ch.6.).

(h) When the bubbles finally burst, many of the highly specialized workers, who have been working in the bubble sectors, will lose their jobs. However, their skills will not be easily transferable and useable in other sectors. This will lead to temporarily high unemployment that cannot be prevented by a fiscal expansion. This happened in the financial and housing sectors, during the bursting of the sub-prime bubble in 2007-2009, sending unemployment rates sharply up.

(i) During economic downturns, especially when they are caused by the busting of bubbles that had built over a long time, and when the government intervenes with a fiscal stimulus, the stimulus cannot create jobs that are good fits for the skills of the workers who have lost their specialized jobs. In some ways this problem bears some similarity to that theorized by Hayek, on the inability of central planners to determine what the needs of the consumers and the producers are in a planned economy. The reason is that the knowledge needed is not available to 
the planners, because it is dispersed throughout an economy. This could be called the "Hayek insufficient-knowledge problem".

The policymakers that make the decisions, on the size and composition of the fiscal stimulus, cannot have the information on what kind of stimulus would be optimal for the economy. Therefore, they cannot design a stimulus program that could help all the differently-skilled workers who have lost their job, and the enterprises that are looking for workers with particular skills. If they had that knowledge and used it, they might also, de facto, replicate the bubble and prevent the necessary reallocation of resources. Inevitably fiscal expansions are likely to create rents for some workers (as they did for bankers during the Great Recession), while they may do little for others. Only time and the Schumpeterian "creative destruction of inefficient activities" (in the bubbles sectors) can bring back the needed equilibrium.

In its decision on which spending to increase, or which taxes to cut, the government is likely to follow the line of least political resistance, paying less attention to what may be needed economically. This is particularly true for the very fragmented and complex economies of today, in which many special interest groups have enough power to influence government decisions (Tanzi 2018a).

Some of the obstacles encountered by the unemployed workers in moving to new, available jobs, may be monetary or psychological, because the new jobs may be in far-away places and moving costs, both financial and psychological, may be high. These costs may become even higher when there are locally imposed "occupational licensing requirements", as they exist in American states, or other regulations, or when housing costs are high (Tanzi 2018a: 124-126). Because of these "requirements", many workers will need to acquire locally issued "licenses", before they are allowed to operate in particular activities in a specific activity in a new geographical area.

The problems of matching skills and places, for workers who have lost their jobs during a downturn is likely to have become more difficult today than it was in Keynes' time, for various reasons. Governments are likely to react to these difficulties by simply increasing the size of the fiscal stimulus, or by sustaining it for a longer period, thus contributing to future fiscal problems. These policies may in time reduce the unemployment rate but at the cost of a fall in the population in the work force.

The importance of the initial fiscal conditions. Countercyclical fiscal policy has been largely silent about the importance of the fiscal conditions of a country at the time when the government is contemplating a fiscal stimulus program (Tanzi 2015b). However, it seems reasonable to assume that, given a forecast of a down- 
turn, and given the size and the quality of a government stimulus program, the impact that that program is likely to have on the economy will depend on the condition of the fiscal accounts at that time, and, perhaps, also on the existing structural obstacles, that may impede the relocation of workers and/or the closing of unproductive activities. Thus the initial structural conditions are also likely to be important.

A country that introduced a fiscal expansion, when (a) it had an already large and costly public debt; (b) had a significant fiscal deficit; and (c) had been facing concerns about the longer run sustainability of its fiscal accounts, would be more likely to face increasing costs of borrowing (increasing "spreads"), and to benefit less from the fiscal stimulus, than countries not facing these conditions. This problem was faced by Italy, Greece and some other countries in recent years, because of their high, initial debts. It was not faced by Spain, Ireland and other countries that entered the crisis with better fiscal (and structural) conditions.

Uncertainty and concerns about the future have a significant but difficult-tomeasure impact on economic decisions. Uncertainty is never neutral in its economic impact. When it is connected with fears of a deteriorating fiscal situation, its impact can easily become significant and negative (Makin 2012, Baker et al. 2014). This points to the importance, for countries, of keeping their fiscal accounts in good shape, during normal times. Good fiscal accounts create positive externalities for the future, and they guarantee that when a fiscal expansion is needed, it will have a higher chance of delivering the hoped-for impact on the economy. Poor initial conditions do the opposite. It is easy to visualize a geometric relationship that could be formalized in an orthogonal graph, in which, ceteris paribus, the higher is the initial public debt, as a share of GDP, the lower will be the multiplier associated with a given fiscal stimulus, and the lower growth prospects for the country in the longer run. Of course, initial, damaging, structural constraints can easily add to that result.

As a final point, bubbles burst because of the misallocation of resources in some sectors that they create. Therefore, when a bubble bursts, some reallocation of resources will be necessary. If structural impediments put obstacles to that reallocation, a fiscal expansion will have less of the desired impact. It is almost embarrassing that this conclusion needs to be stressed, although some convinced Keynesians have dismissed or ignored the importance of structural obstacles. The contrasts, in recent years, between the experiences of Ireland and Spain, on one side, and those of Greece and Italy, on the other, point to the importance of this point. 


\section{CONCLUDING COMMENTS}

This paper has reviewed some traditional and some less traditional criticisms of counter-cyclical fiscal policy, a policy that has been subjected to continuing discussion since it was first proposed, in 1936, by Keynes. However, in spite of the criticisms, that policy has been often used during economic downturns. Its use was strongly advocated by several, well-known economists during the financial crisis of 2007-2008 and the Great Recession that followed. Several governments used it, increasing public spending and creating large fiscal deficits and public debts.

Supporters of that policy have argued that it worked because unemployment fell and economic growth recovered. As evidence they point to the growing activity and lower unemployment in the years that followed. Critics have argued that: (a) it was not necessary, given that the downturns were due to the bursting of bubbles, and not to the weakening of "animal spirits", (b) it prevented or delayed the natural and needed destruction of some bad investments, (c) the countries would have pulled out of the crisis without the extraordinary fiscal actions, and with more sustainable fiscal accounts, and (d) that the countries that did not introduce fiscal stimulus programs did equally well. It is also worth noting that the countries that had had better fiscal accounts before the downturn recovered faster and did better than the others.

The conclusion of this paper is somewhat agnostic and is in part influenced by the author's long and at times direct experience in this area. The author finds some of the claims made by a few economists, about the existence of very large multipliers, not convincing. The proof of that existence has often been achieved by torturing the data, and, as it is generally true with the law of torture, if you apply enough torture to the data, you can get the answer that you want to get.

The paper has also argued that changes in what we have called the socio-economic ecology of countries in recent decades suggest that they may have reduced the power that counter-cyclical fiscal policy may have had in the past. It is hoped that others will study and further analyse that conclusion.

Still, the conclusion could be that a country that has kept its fiscal accounts in relatively good order should not be discouraged from using, with caution, counter-cyclical fiscal policy, in case of severe downturns, especially those not caused by the bursting of bubbles. However, claims that stimulus policies are "wonder drugs" should be dismissed. 


\section{REFERENCES}

Baker, S. R - Bloom, N. - Canes-Wrone, B. - Davis, S. J. - Rodden, J. (2014): Why has US Policy Uncertainty Risen since 1960? American Economic Review: Papers and Proceedings, 104(5): 56-60.

Estrin, S. - Kolodko, G. W. - Uvalic, M. (2007): Transition and Beyond. London: Palgrave MacMillan.

International Monetary Fund (2018): Capitalizing on Good Times. Fiscal Monitor, April.

Kolodko, G. W. (2014): Management and Economic Policy for Development. New York: Nova Publishers.

Makin, J. H. (2012): Financial Crises and Danger of Economic Policy Uncertainty. American Enterprise Institute for Policy Research, Economic Outlook (November).

Meyer, W. (2018): How Labor Regulations Harms Unskilled Workers. Regulation, Summer: 44-50.

Spilimbergo, A. - Symansky, S. - Blanchard, O. - Cottarelli, C. (2008): Fiscal Policy for the Crisis. IMF Staff Position Note, No. 08/01, December 29.

Tanzi, V. (2013): Dollars, Euros, and Debt: How We Got into the Fiscal Crisis, and How We Get out of It. London: Palgrave Macmillan.

Tanzi, V. (2015a): Fiscal and Monetary Policies during the Great Recession. Comparative Economic Studies,57(2): 243-275.

Tanzi, V. (2015b): Crises, Initial Conditions and Economic Policies. In: Structural Reforms and Fiscal Consolidation: Trade Offs or Complements? Presentation on the Symposium, Federal Ministry of Finance (Germany), 25, March, pp. 41-56.

Tanzi, V. (2016): Pleasant Dreams or Nightmares, in the Public Debts Scenarios? ifo Schnelldienst, No. 9.

Tanzi, V. (2018a): Termites of the State: Why Complexity Leads to Inequality. Cambridge University Press.

Tanzi, V. (2018b): The Ecology of Tax Systems. Cheltenham, UK: Edward Elgar Publishing.

Tanzi, V. (2018c): Rethinking Keynesianism 10 Years after the Global Crisis. Acta Oeconomica, 68(S2): 7-19

Tanzi, V. (2018d): The Irresistible Attraction of Public Debt. In: Buchanan, J. M.: A Theorist of Political Economy and Social Philosophy. London: Palgrave Macmillan. Forthcoming.

Tanzi, V. - Chalk, N. (2000): Impact of Large Debt on Growth in the EU: A Discussion of Potential Channels. In: European Economy, Public Debt and Fiscal Policy in EMU, Ch. 2, pp. 23-43. (Republished in Buti, M. - von Hagen, J. - Martinez-Mongay, C. (eds) (2002): The Behavior of Fiscal Authorities. London: Palgrave Macmillan, pp. 186-214). 